DOI: $10.29405 /$ bioeduscience/38-44111180

\title{
Inokulum Mikoriza Arbuskula sebagai Pupuk Hayati pada Tanaman Gandum (Triticum Aestivum L.)
}

\author{
Erwin ${ }^{1, *}$ \\ ${ }^{1}$ Pendidikan PGSD, Universitas Muhammadiyah Prof. Dr. Hamka, Jakarta Timur, Indonesia \\ *E-mail: erwin.kiagus@gmail.com
}

Received: 05 Oktober 2017 | Accepted: 10 November 2017 | Published: 25 Desember 2017

\section{ABSTRAK}

Peranan mikoriza arbuskula (MA) dalam bidang pertanian telah terbukti sangat signifikan, namun terkendala dengan ketersediaan inokulum berkualitas untuk diaplikasikan di lapang. Penelitian ini bertujuan untuk mempelajari karakteristik inokulum MA dan pemanfaatannya sebagai pupuk hayati tanaman Gandum (Triticum aestivum L). Parameter yang diuji pada tanaman gandum ( $T$. aestivum L.) ialah pertumbuhan cendawan mikoriza arbuskula yaitu persen kolonisasi, jumlah entry point, hifa internal, arbuskula dan vesikula, dan pertumbuhan tanaman yaitu tinggi tajuk, berat basah dan kering tajuk, dan berat basah akar. Kolonisasi akar dan struktur cendawan yaitu entry point, hifa internal arbuskula dan vesikula menunjukkan hasil meningkat sehingga bisa dijadikan sebagai jumlah inokulum yang akan diinokulasikan ke tanaman gandum. Peningkatan kolonisasi juga berkorelasi positif dengan pertumbuhan gandum yaitu tinggi tajuk, bobot basah, bobot kering tajuk, dan bobot basah akar. Respon terbaik kolonisasi MA untuk pertumbuhan tanaman gandum diperoleh pada gandum galur Oasis dan SBR, sedangkan respon terendah kolonisasi MA pada tanaman gandum galur S03.

Kata kunci: Inokulum; mikoriza arbuskula; Triticum aestivum; Galur

Copyright (C) 2017 BIOEDUSCIENCE All rights reserved

\section{PENDAHULUAN}

Mikoriza ialah simbiosis mutualisme antara cendawan asal tanah dengan akar tumbuhan yang fungsi utamanya sebagai pupuk hayati. Mikoriza arbuskula ialah salahsatu tipe mikoriza yang membentuk kolonisasi hifa secara interseluler, intraseluler, arbuskula, dan kadangkadang vesikula di dalam akar tumbuhan inang, serta jalinan miselia di dalam tanah yang disebut hifa eksternal (Smith dan Read. 2008). Kualitas inokulum mikoriza arbuskula ditentukan oleh kemampuan cendawan dalam membentuk struktur-struktur simbiosis tersebut.

Mikoriza Arbuskula (MA) sebagai pupuk hayati dapat tumbuh membentuk jalinan hifa mengeksplorasi seluruh rizosfer tanaman inang untuk melakukan penyerapan unsur makro hara diantaranya $\mathrm{P}, \mathrm{K}, \mathrm{N}$ dalam bentuk amonium
(NH4+), $\mathrm{S}, \mathrm{Mg}$ dan $\mathrm{Ca}$, sedangkan jenis unsur mikro yang diserap ialah $\mathrm{Zn}, \mathrm{Cu}, \mathrm{B}, \mathrm{Co}, \mathrm{Fe}, \mathrm{Mn}$, $\mathrm{Cl}, \mathrm{Na}, \mathrm{Mo}$, dan $\mathrm{Si}$, juga mampu menyerap dan melindungi perakaran dari logam berat $\mathrm{Cd}, \mathrm{Ni}$, $\mathrm{Sr}$, Cs dan penyerapan anion $\mathrm{Br}$, I baik di tanah masam, netral maupun basa (Sieverding 1991).

Gandum merupakan tanaman serealia pertanian yang sangat penting. Gandum digunakan sebagai sumber tepung terigu. Salah satu keunggulan gandum adalah kandungan gluteinnya yang mencapai $80 \%$. Glutein adalah protein yang bersifat kohesif dan liat sehingga bahan pangan yang mengandung glutein banyak digunakan untuk membuat roti, mie, biskuit, kue, semolina, bulgar dan sereal (Porter 2005). Respon tanaman gandum terhadap aplikasi mikoriza menunjukkan hasil yang signifikan untuk meningkatkan pertumbuhan gandum 
(Fasaei dan Mayel 2012). Tanaman gandum juga bersifat mikotropik yaitu mampu bersimbiosis dengan cendawan mikoriza arbuskula. Ketergantungan tanaman sorgum dan gandum terhadap mikoriza arbuskula cukup tinggi sehingga sering digunakan sebagai salah satu tanaman inang dalam produksi inokulum mikoriza arbuskula.

Ketersediaan inokulum yang berkualitas sering menjadi kendala dalam pemanfaatan mikoriza arbuskula sebagai pupuk hayati karena cendawannya bersifat simbion obligat yaitu hanya dapat tumbuh jika bersimbiosis dengan arbuskula yang paling murah dan efektif untuk skala aplikasi lapang. Salah satu standar utama yang harus dipenuhi dalam formulasi inokulum ialah viabilitas inokulum yang ditunjukkan dengan kemampuan cendawan dalam mengkolonisasi akar inang dan membentuk struktur-struktur kolonisasi seperti entry point, hifa internal, arbuskula dan vesikula.

Permintaan terhadap inokulum mikoriza arbuskula sebagai pupuk hayati untuk pertanian, perkebunan dan kehutanan di Indonesia sangat tinggi, namun ketersediaan inokulum yang berkualitas dan terformulasi belum tersedia dengan baik. Hampir seluruh tanaman pertanian bersimbiosis dengan mikoriza arbuskula, kecuali familia Brasicaceae, Amaranthaceae, Cruciferae tidak bersimbiosis dan peran simbiosis dalam peningkatan pertumbuhan tanaman baik di rumah kaca maupun di lapang telah terbukti sangat signifikan (Adewole et al. 2010; Jiao et al. 2011). Pemanfaatan mikoriza arbuskula sebagai pupuk hayati di lapang terkendala ketidaktersediaan inokulum dan murah untuk diaplikasikan di lapangan.

\section{MATERI DAN METODE}

Percobaan dilakukan di rumah kaca dan laboratorium. Bahan yang digunakan ialah isolat Glomus manihotis, tanaman inokulum Centrosema pubescens, Pueraria phaseoloides, tanaman aplikasi Triticum aestivum 10 galur impor HP, Oasis, SBR, YMH, Wax, Munal, H20, SO3, SO5, S805, S809, Nias, Selayar.
Prosedur penelitian dilakukan Persiapan media tanam menggunakan zeolit tipe 3 serta persemaian benih kacang sentro, dan kacang kudzu. Produksi inokulum mikoriza arbuskula dengan menginokulasi Glomus manihotis pada tanaman inang perbanyakan sebanyak 250 spora per tanaman.Tanaman dipelihara selama 10 minggu. Penyiraman dilakukan setiap hari dan pemupukan dilakukan setiap minggu menggunakan larutan hara Johnson dengan konsentrasi Phosphor $25 \%$ dari konsentrasi normal. Pada umur tanaman panen, akar tanaman diambil dan dilakukan pengamatan menggunakan metode Philips dan Hayman (1970) dan Giovanetti dan Mosse (1980). Akar yang memiliki kolonisasi lebih dari $70 \%$ digunakan sebagai inokulum untuk aplikasi tanaman lapangan gandum. Pemberian inokulum unggul dilakukan pada tanaman gandum 13 galur. Tanaman dipelihara sampai berumur 30 hari setelah tanam (HST), setiap perlakuan diulang sebanyak 5 kali ulangan. Parameter yang diamati pada tanaman gandum adalah panjang tajuk, bobot basah tajuk, bobot basah akar, bobot kering tajuk, sedangkan struktur MA pada tanaman gandum yang diamati adalah jumlah entry point, hifa internal, arbuskula, vesikula, persen kolonisasi. Percobaan penelitian menggunakan rancangan acak kelompok dengan lima kali ulangan. Data dianalisis secara statistik dengan perangkat lunak SPSS (Statistical Package for Social Science) 17.0 dan perangkat lunak SAS seri 9.0 dan diuji lanjut menggunakan Duncan's Multiple Range Test (DMRT) $\alpha=5 \%$.

\section{HASIL}

Pengaruh inokulum MA pada tanaman gandum (Triticum aestivum L.), berdasarkan data persen kolonisasi yang disajikan pada gambar 1, menunjukkan bahwa seluruh galur gandum ( $\mathrm{T}$. aestivum) yang diuji terkolonisasi dengan cendawan mikoriza arbuskula dengan rentang nilai antara $62 \%$ sampai $80 \%$. 13 galur gandum yang diuji dapat digolongkan ke dalam tiga kelompok berdasarkan pada persen 
kolonisasi yaitu terkolonisasi diatas $75 \%$ seperti galur Oasis, SBR dan HP. Kolonisasi 65- 75\% seperti galur Nias, S805, Munal, H20, Ymh, Wax, S08 dan S09, dan yang dibawah 65\% yaitu galur S03. Nilai kolonisasi cukup tinggimenunjukkan bahwa gandum merupakan tanaman yang cukup responsif terhadap kolonisasi cendawan mikoriza arbuskula, sedangkan perbedaan tingkat kolonisasi antar galur gandum diduga akibat perbedaan respon adaptasi terhadap kondisi lingkungan tropis. Data kolonisasi MA pada tanaman gandum tertera pada gambar 1 .

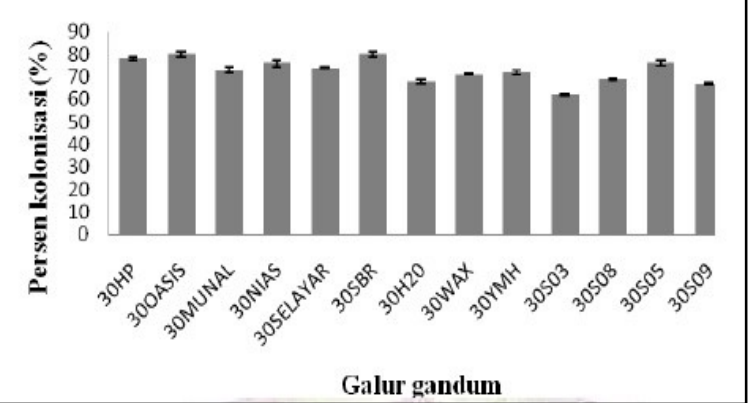

Gambar 1. Persen kolonisasi MA pada akar tanaman 13 galur gandum (T.aestivum L) umur 30 hari setelah diinokulasi (HSI).Data menunjukkan nilai rataan dari lima kali ulangan \pm standar error (SE). jumlah cukup tinggi tiap pot tanaman gandum. (Tabel 1).

Galur Oasis mempunyai jumlah entry point, hifa internal, arbuskula dan vesikula tertinggi jika dibandingkan dengan ke 12 galur lainnya, pola ini sama dengan tingkat persentase kolonisasi dengan galur Oasis paling responsif struktur MA yang terbentuk dan kurang responsi adalah galur SO3 yang terkecil untuk struktur MA yang terbentuk di akar gandum. Bentuk karakter struktur MA yang terbentuk pada akar tanaman gandum ditampilkan pada gambar 2 .

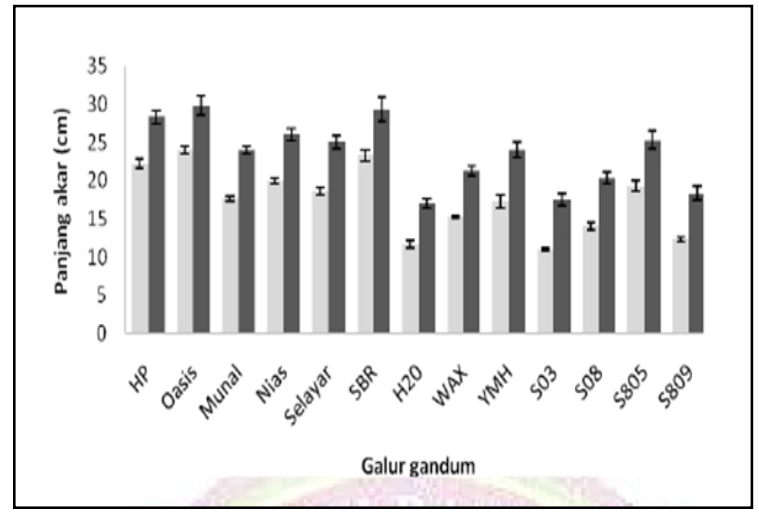

Gambar 2. Struktur mikoriza arbuskula pada akar tanaman 13 galur gandum (T. aestivum L) umur 30 hari setelah diinokulasi tablet inokulum. (a) entry point, (b) hifa internal, (c) arbuskula, (d) vesikula.

Table 1. Struktur cendawan mikoriza arbuskula pada akar tanaman gandum (T. aestivum L) umur 30 hari setelah diinokulasi

\begin{tabular}{ccccc}
\hline Perlakuan & Jumlah titik masuk & Jumlah hifa internal & Jumlah arbuskula & Jumlah veskula \\
\cline { 2 - 3 } & & POT & & \\
HP & $97.6 \pm 0.8 \mathrm{~b}$ & $170.80 \pm 1.8 \mathrm{~b}$ & $125.58 \pm 1.5 \mathrm{~b}$ & $114.40 \pm 1.7 \mathrm{~b}$ \\
MUNAL & $102 \pm 1.7 \mathrm{a}$ & $211.04 \pm 1.4 \mathrm{a}$ & $155.70 \pm 2.3 \mathrm{a}$ & $149.82 \pm 2.9 \mathrm{a}$ \\
OASIS & $93.8 \pm 1.1 \mathrm{e}$ & $148.38 \pm 1.7 \mathrm{e}$ & $108.98 \pm 2.0 \mathrm{e}$ & $94.95 \pm 2.0 \mathrm{e}$ \\
NIAS & $96.6 \pm 0.8 \mathrm{c}$ & $169 \pm 1.7 \mathrm{c}$ & $124.80 \pm 1.5 \mathrm{c}$ & $110.84 \pm 1.7 \mathrm{c}$ \\
SELAYAR & $95 \pm 1.7 \mathrm{~d}$ & $159.39 \pm 3.0 \mathrm{~d}$ & $119.67 \pm 2.0 \mathrm{~d}$ & $105.79 \pm 2.6 \mathrm{~d}$ \\
SBR & $101.3 \pm 1.7 \mathrm{a}$ & $206.02 \pm 2.0 \mathrm{a}$ & $153.24 \pm 1.7 \mathrm{a}$ & $143.57 \pm 3.2 \mathrm{a}$ \\
H2O & $73.8 \pm 0.8 \mathrm{j}$ & $86.98 \pm 1.5 \mathrm{j}$ & $46.13 \pm 1.8 \mathrm{j}$ & $40.53 \pm 1.6 \mathrm{j}$ \\
WAX & $89.2 \pm 1.4 \mathrm{~g}$ & $112.04 \pm 1.7 \mathrm{~g}$ & $77.39 \pm 2.3 \mathrm{~g}$ & $66.03 \pm 1.7 \mathrm{~g}$ \\
YMH & $91.6 \pm 1.7 \mathrm{f}$ & $136.08 \pm 2.0 \mathrm{f}$ & $97.93 \pm 1.4 \mathrm{f}$ & $85.05 \pm 1.7 \mathrm{f}$ \\
S03 & $73.4 \pm 1.2 \mathrm{j}$ & $84.73 \pm 1.4 \mathrm{j}$ & $42.03 \pm 2.0 \mathrm{j}$ & $33.58 \pm 1.4 \mathrm{j}$ \\
S08 & $76.7 \pm 0.5 \mathrm{~h}$ & $101.26 \pm 1.4 \mathrm{~h}$ & $57.68 \pm 2.5 \mathrm{~h}$ & $45.93 \pm 0.8 \mathrm{~h}$ \\
S805 & $96.3 \pm 0.5 \mathrm{c}$ & $167.28 \pm 1.5 \mathrm{c}$ & $123.68 \pm 1.1 \mathrm{c}$ & $108.26 \pm 0.8 \mathrm{c}$ \\
S809 & $75 . \pm 0.8 \mathrm{i}$ & $91.60 \pm 2.5 \mathrm{i}$ & $52.02 \pm 3.1 \mathrm{i}$ & $43.01 \pm 2.1 \mathrm{i}$ \\
\hline
\end{tabular}

Keterangan: angka pada setiap kolom yang diikuti oleh huruf yang sama menunjukkan hasil yang tidak berbeda nyata berdasarkan DMRT pada $\alpha=5 \%$. Data menunjukkan nilai rataaan dari 5 kali ulangan \pm standar error (SE).

Kualitas kolonisasi 13 galur gandum cukup baik yang ditunjukkan dengan terbentuknya struktur MA berupa entry point, hifa internal, arbuskula dan vesikula dalam
Peningkatan koloni dan struktur MA tidak terlepas dari panjang total akar yang terbentuk masing-masing galur gandum dan panjang akar terkolonisasi (Gambar 3). 


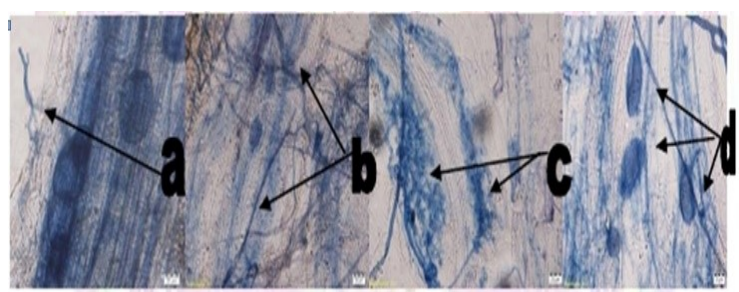

Gambar 3. Panjang akar terkolonisasi ( $\quad$ ), dan total panjang akar ( $\longrightarrow$ tanaman 13 galur gandum (T.aestivum L) tiap pot pada umur 30 hari setelah inokulasi (HSI). Data menunjukkan nilai rataan dari lima kali ulangan \pm standar error (SE).

Tiga belas galur gandum yang diuji pada respon pertumbuhan panjang tajuk, bobot basah dan kering tajuk serta bobot basah akar ditunjukkan pada tabel 2.
Dari tabel 2 terlihat bahwa pertumbuhan akar dan tajuk yang lebih baik masih ditunjukkan oleh galur gandum yang memiliki tingkat persentase kolonisasi yang tinggi. Inokulasi cendawan mikoriza arbuskula meningkatkan pertumbuhan tajuk ke 13 galur gangum dengan peningkatan pertumbuhan secara umum lebih tinggi jika dibandingkan dengan kontrol negatif yaitu kontrol dengan pemupukan unsur P $25 \%$ maupun dengan kontrol positif yaitu kontrol mendapatkan pemupukan unsur P $100 \%$ (Tabel 2). Inokulasi MA pada galur Oasis, SBR, HP, Nias, S805 meningkatkan pertumbuhan panjang tajuk lebih tinggi dari kedua kontrol negatif dan positif

Table 2. Parameter pertumbuhan tanaman gandum (T.aestivum L) pada usia 30 hari setelah diinokulasi

\begin{tabular}{|c|c|c|c|c|}
\hline Perlakuan inokulasi & Panjang tajuk (cm) & Bobot basah (mg) & Bobot kering tajuk & Bobot basah akar (mg) \\
\hline Kontrol negatif & $37 \pm 0.03 \mathrm{i}$ & $692 \pm 1.67 v$ & $68 \pm 1.45 \mathrm{jk}$ & $77 \pm 0.881$ \\
\hline Kontrol positif & $41 \pm 0.12 \mathrm{f}$ & $812 \pm 1.20 \mathrm{o}$ & $82 \pm 1.22 \mathrm{gh}$ & $109 \pm 0.67 \mathrm{f}$ \\
\hline Galur HP & $44 \pm 0.15 b$ & $1232 \pm 0.67 \mathrm{c}$ & $110 \pm 0.33 c$ & $145 \pm 0.67 \mathrm{~b}$ \\
\hline Kontrol negatif & $41 \pm 0.14 \mathrm{~cd}$ & $764 \pm 2.73 \mathrm{j}$ & $81 \pm 0.88$ ghi & $91 \pm 1.20 \mathrm{hi}$ \\
\hline Kontrol positif & $43 \pm 0.1 \mathrm{f}$ & $863 \pm 2.03 \mathrm{~m}$ & $89 \pm 0.67 f$ & $125 \pm 0.57 \mathrm{e}$ \\
\hline Galur Oasis & $46 \pm 0.06 \mathrm{a}$ & $1312 \pm 1.17 \mathrm{a}$ & $169 \pm 0.51 \mathrm{a}$ & $199 \pm 0.38 \mathrm{a}$ \\
\hline Kontrol negatif & $36 \pm 0.08 \mathrm{i}$ & $657 \pm 1.73 x$ & $60 \pm 1.15 n$ & $69 \pm 0.671$ \\
\hline Kontrol positif & $37 \pm 0.06 \mathrm{f}$ & $760 \pm 1.15 \mathrm{r}$ & $78 \pm 0.33 \mathrm{hi}$ & $91 \pm 0.67 \mathrm{i}$ \\
\hline Galur Munal & $42 \pm 0.83 b$ & $1162 \pm 0.88 f$ & $89 \pm 0.88 \mathrm{f}$ & $132 \pm 0.88 \mathrm{~d}$ \\
\hline Kontrol negatif & $37 \pm 0.1 \mathrm{i}$ & $688 \pm 1.67 \mathrm{v}$ & $65 \pm 2.181$ & $75 \pm 1.53 \mathrm{k}$ \\
\hline Kontrol Positif & $40 \pm 0.07 f$ & $799 \pm 1.0 \mathrm{p}$ & $81 \pm 0.33 \mathrm{hi}$ & $97 \pm 0.33 \mathrm{i}$ \\
\hline Galur Nias & $43 \pm 0.50 b$ & $1212 \pm 1.67 \mathrm{~d}$ & $102 \pm 1.33 \mathrm{~d}$ & $139 \pm 0.88 b$ \\
\hline Kontrol negatif & $36 \pm 0.15 \mathrm{i}$ & $660 \pm 0.88 x$ & $61 \pm 0.671 \mathrm{mn}$ & $71 \pm 0.881$ \\
\hline Kontrol positif & $38 \pm 0.06 \mathrm{f}$ & $778 \pm 1.15 q$ & $80 \pm 0.33 \mathrm{hi}$ & $93 \pm 0.67 \mathrm{i}$ \\
\hline Galur Selayar & $42 \pm 0.14 b$ & $1185 \pm 2.60 \mathrm{e}$ & $94 \pm 0.33 \mathrm{e}$ & $134 \pm 1.15 \mathrm{~cd}$ \\
\hline Kontrol negatif & $38 \pm 0.18 \mathrm{i}$ & $712 \pm 0.88 \mathrm{u}$ & $70 \pm 0.33 \mathrm{j}$ & $81 \pm 0.57 \mathrm{j}$ \\
\hline Kontrol positif & $42 \pm 0.03 \mathrm{fe}$ & $832 \pm 1.20 \mathrm{n}$ & $85 \pm 0.88 f$ & $118 \pm 0.67 f$ \\
\hline Galur SBR & $45 \pm 0.43 a$ & $1285 \pm 1.15 b$ & $146 \pm 0.88 b$ & $197 \pm 0.57 \mathrm{a}$ \\
\hline Kontrol negatif & $32 \pm 0.08 \mathrm{j}$ & $562 \pm 1.20 \mathrm{dd}$ & $51 \pm 0.88 p$ & $59 \pm 0.67 \mathrm{~m}$ \\
\hline Kontrol positif & $32 \pm 0.05 \mathrm{gh}$ & $642 \pm 0.88 y$ & $65 \pm 0.88 \mathrm{k}$ & $79 \pm 0.331$ \\
\hline Galur H2O & $41 \pm 0.17 \mathrm{c}$ & $1009 \pm 0.88 \mathrm{k}$ & $80 \pm 0.57 \mathrm{ghi}$ & $90 \pm 0.88 \mathrm{hi}$ \\
\hline Kontrol negatif & $34 \pm 0.12 \mathrm{i}$ & $597 \pm 1.45 \mathrm{aa}$ & $55 \pm 1.53$ op & $63 \pm 0.88 \mathrm{~m}$ \\
\hline Kontrol positif & $35 \pm 0.12 \mathrm{fg}$ & $739 \pm 0.57 \mathrm{t}$ & $75 \pm 0.33 \mathrm{j}$ & $88 \pm 0.67 \mathrm{j}$ \\
\hline Galur Wax & $41 \pm 0.08 \mathrm{~cd}$ & $1086 \pm 2.96 \mathrm{~h}$ & $83 \pm 0.57 \mathrm{~g}$ & $93 \pm 1.20 \mathrm{~h}$ \\
\hline Kontrol negative & $34 \pm 0.08 \mathrm{i}$ & $599 \pm 1.33 \mathrm{aa}$ & $55 \pm 0.57 \mathrm{o}$ & $63 \pm 0.33 \mathrm{mn}$ \\
\hline Kontrol positif & $36 \pm 0.06 \mathrm{~h}$ & $750 \pm 0.88 \mathrm{~s}$ & $77 \pm 0.88 \mathrm{hi}$ & $88 \pm 0.57 \mathrm{j}$ \\
\hline Galur Ymh & $41 \pm 0.05 \mathrm{~d}$ & $1122 \pm 1.20 \mathrm{~g}$ & $87 \pm 0.88 \mathrm{f}$ & $97 \pm 1 \mathrm{~g}$ \\
\hline Kontrol negatif & $30 \pm 0.05$ & $548 \pm 1.15$ ee & $50 \pm 0.33 p$ & $58 \pm 0.57 \mathrm{~m}$ \\
\hline Kontrol positif & $31 \pm 0.03 \mathrm{~h}$ & $611 \pm 1.20 \mathrm{z}$ & $60 \pm 0.33 \mathrm{mn}$ & $75 \pm 1.331$ \\
\hline Galur S03 & $40 \pm 0.08 \mathrm{de}$ & $994 \pm 2.331$ & $79 \pm 0.67 \mathrm{i}$ & $89 \pm 0.67 \mathrm{i}$ \\
\hline Kontrol negatif & $33 \pm 0.14 \mathrm{j}$ & $587 \pm 1.67 \mathrm{bb}$ & $54 \pm 1.0 \mathrm{p}$ & $62 \pm 0.67 \mathrm{~m}$ \\
\hline Kontrol Positif & $33 \pm 0.08 \mathrm{~h}$ & $674 \pm 0.57 w$ & $69 \pm 0.67 j$ & $83 \pm 1.201$ \\
\hline Galur S08 & $41 \pm 0.12 \mathrm{~cd}$ & $1067 \pm 1.46 \mathrm{j}$ & $81 \pm 0.33 \mathrm{ghi}$ & $91 \pm 0.88 \mathrm{hi}$ \\
\hline Kontrol negatif & $36 \pm 0.17 \mathrm{j}$ & $674 \pm 2.33 w$ & $63 \pm 1.211 \mathrm{~m}$ & $72 \pm 0.571$ \\
\hline Kontrol positif & $40 \pm 0.12 \mathrm{~h}$ & $798 \pm 1.15 p$ & $81 \pm 0.88 \mathrm{hi}$ & $96 \pm 0.57 \mathrm{hi}$ \\
\hline Galur 805 & $42 \pm 0.05 \mathrm{~cd}$ & $1206 \pm 1.45 \mathrm{i}$ & $100 \pm 0.57 \mathrm{~d}$ & $136 \pm 0.57 \mathrm{c}$ \\
\hline Kontrol negatif & $33 \pm 0.06 \mathrm{i}$ & $580 \pm 0.33 \mathrm{cc}$ & $53 \pm 1.33 p$ & $61 \pm 0.731$ \\
\hline Kontrol positif & $33 \pm 0.08 \mathrm{~h}$ & $673 \pm 1.45 w$ & $69 \pm 0.67 \mathrm{j}$ & $82 \pm 1.331$ \\
\hline Galur 809 & $41 \pm 0.14 \mathrm{~cd}$ & $1064 \pm 2.73 \mathrm{j}$ & $81 \pm 0.88 \mathrm{ghi}$ & $91 \pm 1.20 \mathrm{hi}$ \\
\hline
\end{tabular}

Keterangan: angka pada setiap kolom yang diikuti oleh huruf yang sama menunjukkan hasil yang tidak berbeda nyata berdasarkan DMRT pada $\alpha=5 \%$. Data menunjukkan nilai rataan dari lima kali ulangan \pm standar error (SE). 
tersebut. Sedangkan pada galur Munal, Selayar, lebih sedikit baik pertumbuhan panjang tajuk dibandingkan kontrol positif, sedangkan galur YMH, Wax, H20, S08, S09, S03 peningkatan pertumbuhan akibat kolonisasi mikoriza setara dengan pemupukan dosis normal (100\%) kontrol positif. Hal ini menunjukkan bahwa kolonisasi MA sangat penting untuk pertumbuhan dan keberhasilan adaptasi tanaman gandum dengan iklim daerah tropis.

Dari ke 13 galur yang diuji, Oasis dan SBR ialah galur yang sangat responsif terhadap kolonisasi MA. Hal ini terlihat dari peningkatan pertumbuhan tajuknya ialah terbesar jika dibandingkan dengan 11 galur lainnya. Peningkatan pertumbuhan gandum galur Oasis pada perlakuan inokulasi lebih dari $100 \%$ jika dibandingkan dengan kontrol negatif dan kontrol positif. Hal ini diduga karena kedua galur tersebut selain mempunyai persen kolonisasi tertinggi juga mempunyai jumlah struktur MA yaitu entry point, hifa internal, arbuskula dan vesikula paling tinggi dibandingkan 12 galur yang diuji.

Dari empat struktur MA yang terbentuk di akar, hifa internal mempunyai jumlah lebih tinggi. Hal ini sesuai dengan Smith dan Read (2008) melaporkan bahwa hifa internal ialah struktur utama yang terbentuk di dalam akar yang selanjutnya merupakan struktur yang akan berkembang membentuk arbuskula dan kadangkadang vesikula. Arbuskula yang terbentuk memiliki umur antara 2-14 hari yang kemudian dapat tumbuh kembali atau arbuskula dibentuk pada tempat yang baru. Vesikula ialah struktur yang terbentuk pada tahapan akhir proses kolonisasi dan berfungsi sebagai cadangan makanan cendawan MA. Dari data tersebut diatas menunjukkan bahwa kualitas inokulum hasil formulasi berupa tablet dalam penelitian ini mempunyai kualitas yang baik.

Mikoriza ialah simbiosis mutualisme antara cendawan dan tumbuhan, oleh karena itu tingkat kolonisasi cendawan pada akar akan mempengaruhi tingkat pertumbuhan tanaman inangnya. Dari pertumbuhan tanaman inang sorgum yang baik, maka diujicobakan formulasi terbaik sebanyak 30 tablet inoculum pada tanaman uji selanjutnya yaitu gandum menggunakan sebanyak 13 galur gandum yang berasal dari introduksi gandum impor subtropis ke kawasan tropis untuk dikembangkan di Indonesia. Pada inokulasi tablet MA terhadap 13 galur gandum juga didapatkan hasil yang memiliki pola mirip sama dengan tanaman sorgum, didapatkan pertumbuhan 13 galur gandum meningkat dengan pemberian inokulum MA jika dibandingkan dengan tanpa pemberian inokulum MA hanya diberi pemupukan P 100\% dan P 25\%. Peningkatan kolonisasi, struktur MA yang terbentuk di akar, dan peningkatan laju pertumbuhan panjang tajuk, bobot basah, bobot kering tajuk, dan bobot basah akar pada ke 13 galur gandum menghasilkan ukuran variasi. Hal ini diduga karena tanaman gandum adalah tanaman tropis dan tanaman kategori C3 sehingga pengembangannya selama ini masih di daerah dataran tinggi yang memiliki iklim mirip dengan lingkungan subtropis, khususnya suhu rendah. Wahyu et al. (2013) menyatakan adanya variasi lingkungan tidak akan menjamin suatu genotipe atau varietas tanaman gandum akan tumbuh baik dan memberikan hasil panen tinggi di semua wilayah. Hal ini terkait dengan kemungkinan ada tidaknya interaksi antara galur tanaman gandum dengan kisaran keragaman lingkungan terutama suhu, kelembaban, lama penyinaran dan intensitas penyinaran. Memahami mekanisme genetik dan fisiologis tanaman gandum sangat penting untuk menciptakan strategi efisien untuk mengembangkan kultivar gandum tahan cekaman suhu tinggi untuk sistem produksi yang berkelanjutan (Rao 2001).

13 galur gandum yang diuji, Oasis ialah galur yang sangat responsif terhadap kolonisasi MA dan struktur MA berupa entry point, hifa internal, arbuskula, dan vesikula yang terbentuk di akar juga tinggi. Dari persentase kolonisasi yang beragam dan tetap tinggi jika dibandingkan tanpa pemberian MA pada galur tanaman 
gandum, menunjukkan gandum bersifat mikotropik yaitu tanaman yang mampu bersimbiosis dengan cendawan mikoriza arbuskula. Hal ini sesuai dengan penelitian (Sing dan Adholeya, 2004) juga didapatkan pada perlakuan berbagai varietas gandum dengan aplikasi MA memberikan repson pertumbuhan yang beragam pada tanaman gandum.

Arbuskula merupakan tempat terjadinya transfer nutrisi termasuk unsur fosfat dari cendawan kedalam akar tanaman sedangkan hifa internal merupakan tempat transfer unsur karbon dari tanaman inang ke dalam cendawan (Karandashov dan Marchel, 2005). Tingginya jumlah arbuskula menyebabkan tanaman mendapatkan sumber nutrisi yang cukup dari cendawan MA yang diserap melalui hifa eksternal yang tumbuh mengeksplorasi media tumbuh tanaman (Bucking et al. 2012; Koltai dan Kapulnik, 2010). Selain itu tingginya jumlah hifa internal menyebabkan cendawan mendapatkan cukup nutrisi untuk pertumbuhannya termasuk untuk pembentukan jalinan hifa yang berfungsi menyerap nutrisi sebagai perpanjangan dari rambut akar (Aguilar et al. 2009). Oleh karena itu, alokasi unsur karbon yang cukup dari tanaman inang kepada cendawan akan menyebabkan transfer nutrisi dari cendawan ke dalam tanaman inang juga meningkat (Parniske, 2008).

Pertumbuhan panjang tajuk, bobot basah dan kering tajuk, serta bobot basah akar pada galur Oasis, SBR, HP, S805, Nias menunjukkan pemberian inokulum MA maupun kontrol positif dan kontrol negatif tetap memberikan respon pertumbuhan terbaik dibandingkan galur gandum lainnya, pada galur gandum lainnya respon terbaik terdapat pada perlakuan pemberian inokulum MA. Dari data 13 galur gandum yang semuanya mampu mempercepat pertumbuhan dengan pemberian inokulum MA berarti inokulum MA juga tetap berkualitas baik untuk pupuk hayati pada tanaman gandum sehingga berpeluang galurgalur gandum yang diujicobakan untuk dikembangkan di Indonesia.

Peran cendawan mikoriza arbuskula dalam pertumbuhan gandum diduga tidak saja melalui penyediaan unsur hara dan hormon pertumbuhan, namun juga berperan dalam resistensi tanaman terhadap kekeringan untuk tetap tumbuh (Al- Karaki et al. 2004; Hooda et al. 2008). Membantu dalam peningkatan kadar klorfil $a$ dan $b$ pada tanaman gandum yang mengalami cekaman kekeringan (Mouchechi et al. 2012). Hal ini karena jalinan-jalinan miselia yang tumbuh di daerah rizosfer berfungsi tidak saja dalam penyerapan nutrisi tetapi juga dalam penyerapan air dan proteksi tanaman terhadap serangan penyakit (Morales et al. 2012). Tanaman bersimbiosis umumnya resistensi terhadap kekeringan (Song, 2005).

\section{KESIMPULAN}

Pemberian inokulum mikoriza arbuskula mampu meningkatkan pertumbuhan dan biomassa tanaman gandum. Respon setiap galur tanaman gandum menunjukkan hasil yang baik dengan menghasilkan kolonisasi mikoriza arbuskula beragam tinggi diatas $50 \%$, Kolonisasi terendah pada gandum galur $\mathrm{SO} 3$ sebesar $62 \%$ dan kolonisasi tertinggi pada galur Oasis dan SBR sebesar $80 \%$.

\section{DAFTAR PUSTAKA}

Adewole MB, Awotoye DO, Ohienbor MO, Salami AO. 2010. Influence of mycorhiza fungi on phytoremediating potential and yield of sunflower in $\mathrm{Cd}$ and $\mathrm{Pb}$ polluted soils. $\mathrm{J} \mathrm{Agr}$ Sci 55(1): 17-28.

Aguilar C, Barea JM, Gianinazzi V, Pearson VG. 2009. Mycorrhizal Functional Processes and Ecological Impact. Berlin (DE): SpringerVerlag.

Al-Karaki GN, McMichael B, Zahl J. 2004. Field response of wheat to arbuscular mycorrhizal fungi and drought stress. Mycorrhiza 14: 263269 
Bucking H, Liepold E, Amilwade P. 2012. The role the mycorrhizal symbiosis in nutrient uptake of plants and the regulatory mechanisms underlying these transport processes. J Plant Sci 53:1593-1601.

Brundrett M. N Bougher. B Dell. T Groove. N Malajczuk. 1996. Working with Mycorrhizas in Forestry and Agriculture. Wembley (AU) CSIRO Centre for Meditrreanean Agriculture Research.

Fasaei RG, Mayel S. 2012. Influence of arbuscular mycorrhizal fungus, phosphorus and zinc on wheat grown on a calcareous soil international research. J Applied Bas Sci 3(7):1411- 1416.

Giovanetti M, Mosse B. 1980. An evaluation of techniques for measuring vesicular-arbuscular mycorrhizal infection in root. New Phytol 84:489-500.

Hooda H, Ghalia A, Khalafallah A. Responses of wheat plants associated with arbuscular mycorrhizal fungi to short term water stress followed by recovery at three growth stages. $J$ App Sci Res. 4: 570- 580.

Jiao H, Chen Y, Lin X, Liu R. 2011. Diversity of arbuscular mycorrhizal fungi in greenhouse soils continously planted to watermelon in North China. Mycorrhiza21: 681- 688.doi. 10.1007/500572-011-0377-z.

Karandashov V, Nagy R, Wegmuller S, Amrhein N, Bucher M. 2004. Evolutionary conservation of a phosphatte transporter in the arbuscular mycorrhizal symbiosis. PNAS 101: 6285-6290.

Morales VC, Navarro RC, Garrido JMG, Illana A, Ocampo JA, Steinkellner S, Vierheilig H. 2012. Bioprotectif agains Gaeumannomyces graminis in barley-ce comparison between arbuscular mycorrhizal fungi. Plant Soil Envir 58(6) : 256-267.

Mosse B. 1981. Vesicular arbuscular mycorrhiza for tropical agriculture. Hawaii Institute of tropical Agriculture and Human Resources. University of Hawaii (US) $82 \mathrm{p}$

Mouchechi A, Heidar B, Assad MT. 2012. Allevation of drought stress effects on wheat using arbuscular mycorrhizal symbiosis. J Agri Sci. 2: $35-47$

Parniske M. 2008. Arbuscular mycorrhiza: the mother of plant root endosymbioses. Nat Microbiol. $6: 763-775$

Philips JM, Hayman DS. 1970. Improved procedures for clearing and staining parasitic and vesicular-arbuscular mycorrhizal fungi for rapid assesment of infection. Trans $\mathrm{Br} \mathrm{Mycol}$ Soc. 55:158-161

Porter JR. 2005. Rising temperatures are likely to reduce crops yields. Nature (496) : 256-269.

Rao IM. 2001. Role of physiology in improving crop adaptation to abiotic stresses in the tropics: the case of common bean and tropical forages in handbook of plant and crop physiology second edition (ed.) (US):Universiy of Arizona.
Sieverding E. 1991. Vesicular-Arbuscular Mycorrhiza Management in Tropical Agrosystems. Eschborn (GE): Deutche Gesellschaft fur.

Sing R, Adholeya A.2004. Teting the symbiotic performance of different genetic cultivars of wheat with selected arbuscular mycorrhizal fungi. Mycorrhiza 16:18-19.

Song g, S., 2011. Effect of elevated levels of carbon dioxide light on mycorrhiza .TERI. 16:2-11

Susilo \& Suciati, R. 2013. Variasi morfologi dan pola pita isozim cendawan Mikoriza arbuskula pada sistem perakaran Tanaman durian (Durio zibethinus Murr.). SIGMA Journal. 2(5):1-9.

Smith SE, Read DJ. 2008. Mycorrhizal Symbiosis. Third Edition. California (US): Academic Press.

Wahyu Y, Samosir AP, Budiarti SG. 2013. Adaptabilitas genotipe gandum introduksi di dataran rendah. Bul Agrohorti. 1 (1) : 1-6. 